Article

\title{
Double-Double Row Planting Mode at Deficit Irrigation Regime Increases Winter Wheat Yield and Water Use Efficiency in North China Plain
}

\author{
Xun Bo Zhou®, Guo Yun Wang, Li Yang and Hai Yan $\mathrm{Wu} * \mathbb{C}$ \\ Guangxi Key Laboratory of Agric-Environment and Agric-Products Safety, National Demonstration Center for \\ Experimental Plant Science Education, Agricultural College of Guangxi University, Nanning 530004, China; \\ xunbozhou@gxu.edu.cn (X.B.Z.); yuanyiwanggy@yeah.net (G.Y.W.); m18746610571@163.com (L.Y.) \\ * Correspondence: wuhy@gxu.edu.cn; Tel.: +86-771-3235612
}

Received: 18 July 2020; Accepted: 1 September 2020; Published: 3 September 2020

check for updates

\begin{abstract}
Low water availability coupled with poor planting method has posed a great challenge to winter wheat (Triticum aestivum L.) productivity. To improve productivity and water use efficiency (WUE) under deficit irrigation, an effective water-saving technology that is characterized by three planting modes has been developed (uniform with 30-cm row spacing $(\mathrm{U})$, double-double row spacing of $5 \mathrm{~cm}$ (DD), and furrow-ridge row spacing of alternated $20 \mathrm{~cm}$ and $40 \mathrm{~cm}(\mathrm{~F}))$ combined with three irrigation regimes (50 mm water each at growth stage 34 (GS34) and GS48 (W1), and $100 \mathrm{~mm}$ water at GS48 (W2), or $100 \mathrm{~mm}$ each water at GS34 and GS48 (W3)). Results showed that DD increased yield by $9.7 \%$ and WUE by $12.6 \%$ due to higher soil water status and less soil water depletion and evapotranspiration compared with U. Although the soil water status, soil water depletion, evapotranspiration, and yield increased with increasing irrigation amount, more soil water depletion and evapotranspiration resulted in low WUE. The deficit irrigation was beneficial for improving WUE as W1 had significantly increased yield by $5.4 \%$ and WUE by $7.1 \%$ compared with W2. Yield and evapotranspiration showed a quadratic dynamic equation indicating that yield increased with increasing evapotranspiration. Considering WUE and relatively higher yield under deficit water, W1 combined with DD is suggested to be a good management strategy to be applied in winter wheat of water-scarce regions.
\end{abstract}

Keywords: Triticum aestivum L.; planting mode; irrigation regimes; soil water status

\section{Introduction}

Winter wheat (Triticum aestivum L.), as the second primary crop, is widely cultivated in the North China Plain, which is the most significant production area in China [1]. To feed 9.4 billion population sustainably until 2050, it is required to produce greater yield [2]. Mean annual cumulative precipitation during the winter wheat growing season (from October to June) was $259 \mathrm{~mm}$ (1971-2014) while evapotranspiration is 400 to $500 \mathrm{~mm}$ [3]; thus, precipitation is not enough for wheat to reach its full potential or maximize yields as demonstrated by irrigated studies [4-6]. In recent years, however, continuous over-exploitation of groundwater for irrigation at current cropping systems has led to decline of water level in both deep and shallow aquifers [7,8]. At the same time, poor irrigation management practices resulted in very low agricultural water use efficiency that still exists and aggravates the water crisis situation $[9,10]$. Therefore, the development of new management practices for crops such as water-saving technologies (e.g., deficit irrigation and irrigation methods) and new planting patterns is imperative to produce more crop per drop and fully utilize the limited water resource to improve the water use efficiency (WUE). 
The WUE for grain production can be an important parameter defining the productivity of crops in water-limited environments [11], which can be improved by different agronomical practices such as irrigation technologies and planting patterns [5,12]. Plants, on the basis of improving WUE, may be expected to show relatively high productivity under water-limited conditions [13]. Furthermore, the soil water status of rooting systems is essential for improving winter wheat productivity $[14,15]$. It is thereby essential to optimize reasonable irrigation strategies and planting modes in the field to decrease soil evaporation and to increase WUE to develop the sustainable crop production for winter wheat. The spatial distribution patterns, e.g., uniform row, furrow-ridge row, and double-double row plantings, will affect individual plant growth, leading to the changes in the population structure [16], soil water signals, such as soil water content and evapotranspiration, WUE, and yield $[5,6]$. On the one hand, the furrow-ridge planting by changing surface plays a crucial role in improving water availability. Compared with conventional planting, furrow-ridge row planting with higher soil water content has led to higher grain yield and WUE as it changes the crop structure to reduce water loss [12,17]. Ali et al. [15] also reported that the increase in the soil water content, grain yield, and WUE of winter wheat were identified in the furrow-ridge row planting combined with 75-mm irrigation by reducing evapotranspiration. Moreover, planting in the furrow had lower soil evaporation than that on the ridge in the furrow because there was more shading in the wetted area for planting in the furrow [18]. On the other hand, double-double row planting had been put forward to explore water-saving mechanism, which was found to increase the soil water content, grain yield, and WUE [12]. Although previous studies focused on the research of furrow-ridge row $[13,19,20]$ and double-double row plantings [21,22], indicating the best planting mode to increase WUE and yield, the comparison between furrow-ridge row and double-double row plantings had not been researched up to now. Consequently, it is important to explore the best planting pattern between them to improve grain yield and WUE of winter wheat at deficit water.

Besides planting mode, another high-efficient agricultural practice was to improve WUE and yield by optimized irrigation including irrigation time, amount, and frequency $[11,23,24]$. Irrigation from jointing to anthesis could increase evapotranspiration during the growing season, grain yield, harvest index, and WUE based on yield [24]. Wang et al. [11] also found that soil water content, evapotranspiration, and grain yield of winter wheat were increased with increasing irrigation amount, but the WUE showed the opposite trend. To minimize irrigation water use and maintain a relatively high WUE and yield, deficit irrigation had been suggested to make irrigation volume below full crop-water requirements [25], which had been widely used in winter wheat [24,26]. Water deficit will reduce the leaf elongation rate, leaf potential, stomatal conductance, nutrient uptake [27], and evapotranspiration [5]. The soil water depletion as an important element for determining seasonal evapotranspiration contributed $40-50 \%$ of the seasonal evapotranspiration under deficit irrigation [28]. The different irrigation amounts at deficit in winter wheat vary greatly from $60 \mathrm{~mm}$ to $135 \mathrm{~mm}$ [22,29]. Based on the South to North Water Transfer project, Yuan et al. [30] also suggested 130-mm/year irrigation to maintain current wheat yield without groundwater declining. Thus, it is important to explore the optimal irrigation amount applied in winter wheat. Apart from irrigation amount, irrigation frequency is also an important factor for water saving of winter wheat, which will influence the soil water content in topsoil layers, evapotranspiration, WUE, and grain yield [29]. Higher grain yield was detected in irrigation at jointing and heading stages than that in a single irrigation [26]; nevertheless, improving irrigation frequency from two to three times was unable to affect the yield [29]. Therefore, two times of irrigation at the jointing and heading stages may be the best choice for developing deficit irrigation regimes of winter wheat in North China Plain.

Although many researchers have been focused on improving WUE and yield by many different agricultural technologies based on increasing soil water status and reducing evapotranspiration, further research is still needed based on the planting mode and irrigation regimes. The objective of this study was to monitor the effects of irrigation regimes and planting methods on winter wheat soil water content, soil water storage, soil water depletion, evapotranspiration, WUE, and grain yield at different 
growth stages of various soil profiles. This study also determined the relationship between grain yield and evapotranspiration. The tested hypothesis was that improvement of irrigation schedules and planting modes would increase grain yield and WUE in the arid region of the North China Plain.

\section{Materials and Methods}

\subsection{Experimental Site Description}

The experiment was conducted at the Agronomy Experimental Station of Shandong Agricultural University (Tai'an, Shandong, latitude $36^{\circ} 09^{\prime} \mathrm{N}$, longitude $117^{\circ} 09^{\prime} \mathrm{E}, 134 \mathrm{~m}$ altitude) in China from October 2014 to June 2016. During the growing season in 1971-2014, the mean monthly maximum temperatures at the site were $-1.7^{\circ} \mathrm{C}$ in January and $24.7^{\circ} \mathrm{C}$ in June, and the mean annual cumulative precipitation was $259 \mathrm{~mm}$ (Figure 1). The mean monthly temperatures and annual cumulative precipitation during winter wheat growing season were $10.7^{\circ} \mathrm{C}$ and $165.2 \mathrm{~mm}(2014 / 15), 10.8^{\circ} \mathrm{C}$ and $197.2 \mathrm{~mm}$ (2015/16), respectively. The soil texture of the experimental field (2014-2016) was silt loam, and the $0-20-\mathrm{cm}$ soil layer was characterized by a $\mathrm{pH}$ of 6.9 , field capacity of $38.6 \%(\mathrm{~V} / \mathrm{V}, \%)$, soil bulk density of $1.50 \mathrm{~g} \mathrm{~cm}^{-3}$, soil organic matter of $18.9 \mathrm{~g} \mathrm{~kg}^{-1}$, and available $\mathrm{N}, \mathrm{P}$, and $\mathrm{K}$ of $123.2 \mathrm{mg} \mathrm{kg}^{-1}$, $40.6 \mathrm{mg} \mathrm{kg}^{-1}$, and $124.5 \mathrm{mg} \mathrm{kg}^{-1}$, respectively.

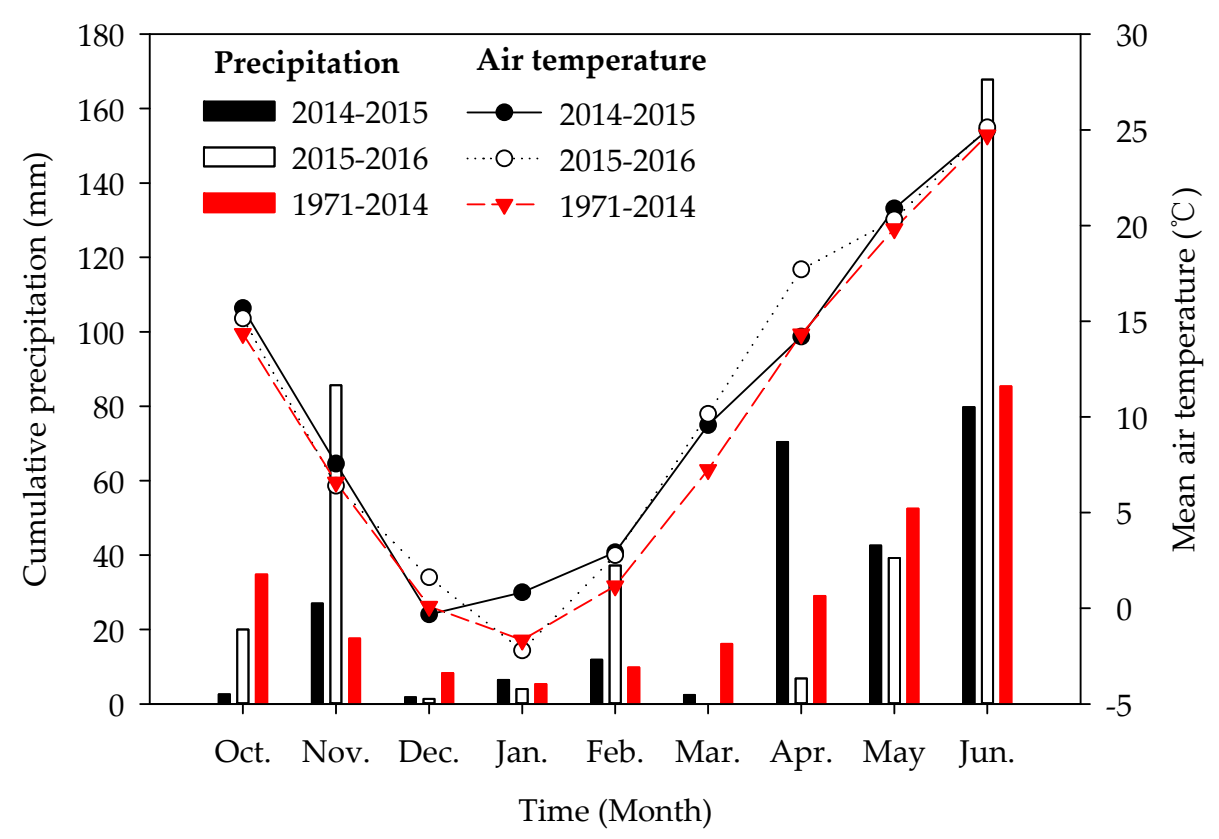

Figure 1. Cumulative monthly precipitation and mean monthly air temperature of winter wheat during 2014-2016 and 1971-2014.

\subsection{Experimental Design and Crop Management}

The experiment was conducted in a split-plot arrangement with three replicates per experimental treatment. The main plot was the following three irrigation schedules: Irrigation $50 \mathrm{~mm}$ water each at growth stage 34 (GS34) and GS48 (W1) [31], irrigation $100 \mathrm{~mm}$ water at GS34 (W2), and irrigation $100 \mathrm{~mm}$ water each at GS34 and GS48 (W3, Table 1). The treatments with time and irrigation amounts are listed in Table 2. Water was supplied to the plots using plastic pipes, and a flow meter was used to measure the irrigation amount. The plot structure was buried on all four sides by using concrete slabs with 2-m depth and 15-cm width in the field, which could prevent the lateral flow of soil water. The split-plot consisted of the following three planting modes: Uniform row $(U$, row spacing of $30 \mathrm{~cm})$, double-double row (DD, a narrow row spacing of $5 \mathrm{~cm}$, a wide row spacing of $15 \mathrm{~cm}$ ), and furrow-ridge row plantings (F, Figure 2). The row spacing was alternated wide-narrow row spacing of $15 \mathrm{~cm}$ and $5 \mathrm{~cm}$ (double rows) for DD, and that of $40 \mathrm{~cm}$ (ridge) and $20 \mathrm{~cm}$ (double rows in furrow) for $\mathrm{F}$. 
After harvest of summer maize, winter wheat (cultivar Jimai 22) with a plant density of $400 \times 10^{4} \mathrm{ha}^{-1}$ was planted manually on 8 October 2014 and 7 October 2015 and harvested on 7 June 2015 and 7 June 2016. Each experimental plot area was $3 \times 3 \mathrm{~m}^{2}$, and each plot had 10 rows of wheat for $U$ and F, 30 rows of wheat for DD. The seedlings were thinned by hand at 15 days after emergence to ensure an initial population density of $200 \times 10^{4}$ plant ha $^{-1}$, and the final seedlings for three planting modes are shown in Figure 3. Prior to sowing, $112.5 \mathrm{~kg} \mathrm{ha}^{-1}, 120 \mathrm{~kg} \mathrm{ha}^{-1}$, and $105 \mathrm{~kg} \mathrm{ha}^{-1} \mathrm{~N}, \mathrm{P}_{2} \mathrm{O}_{5}$, and $\mathrm{K}_{2} \mathrm{O}$ as base mineral fertilizers (urea, $\mathrm{N}$ content $46 \%$; ammonium phosphate, $\mathrm{N}$ content $21 \%, \mathrm{P}_{2} \mathrm{O}_{5}$ content $53 \%$; potassium sulfate, $\mathrm{K}_{2} \mathrm{O}$ content $52 \%$ ) were added to the soil. Then, $112.5 \mathrm{~kg} \mathrm{ha}^{-1} \mathrm{~N}$ was applied as a top dressing during the stem elongation stage (GS30).

Table 1. Description of growth stage scales.

\begin{tabular}{cc}
\hline Zadok Scale [28] & Description \\
\hline 1 & Start of imbibition \\
24 & Main shoot and 4 tillers \\
30 & Pseudo stem erection \\
35 & 5 th node detectable \\
44 & From flag leaf sheath extending to boots just swollen \\
48 & First awns begin \\
49 & First awns visible \\
71 & Kernel watery ripe \\
80 & Dough begin \\
91 & Kernel hard (difficult to divide with thumbnail) \\
\hline
\end{tabular}

Table 2. The amount and time of irrigation during the growing season of winter wheat in 2014-2016.

\begin{tabular}{cccc}
\hline \multirow{2}{*}{ Treatments } & GS34 & GS48 & Total Irrigation (mm) \\
\cline { 2 - 3 } & (27 March 2015, 27 March 2016) & (26 April 2015, 25 April 2016) & \\
\hline W1 & 50 & 50 & 100 \\
W2 & 100 & 0 & 100 \\
W3 & 100 & 100 & 200 \\
\hline
\end{tabular}

a

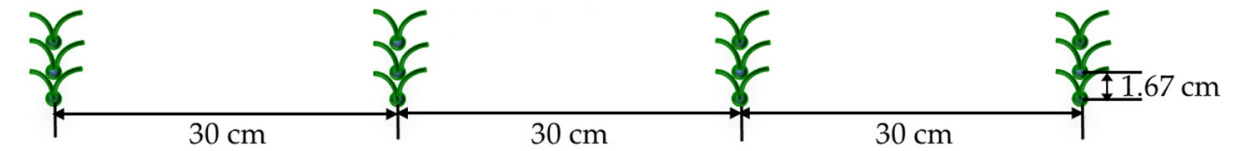

$\mathrm{b}$
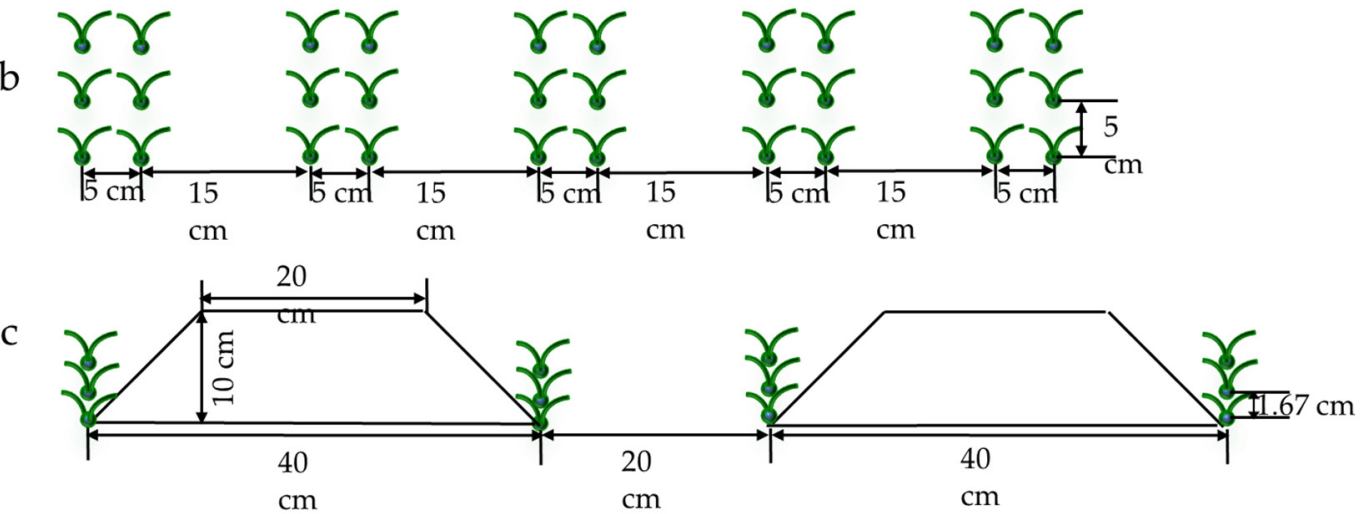

Figure 2. Schematic diagram of planting mode. (a) Uniform row (U), (b) double-double row (DD), (c) furrow-ridge row $(\mathrm{F})$. 


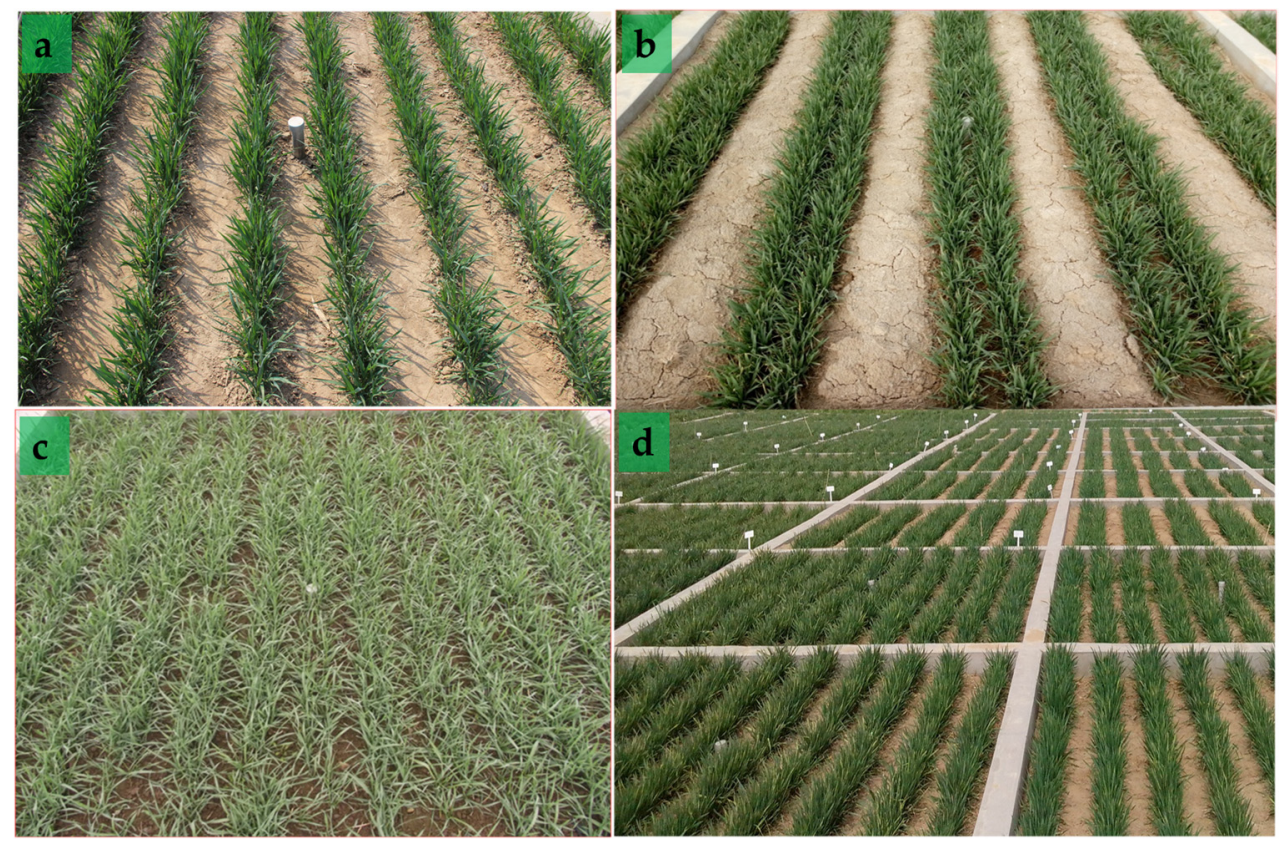

Figure 3. Field pictures of uniform row (a), furrow-ridge row (b), double-double row (c), and whole plots of concrete plot structure (d).

\subsection{Sampling and Calculations}

\subsubsection{Winter Wheat Yield}

The winter wheat yield $\left(\mathrm{g} \mathrm{m}^{-2}\right)$ was measured with $1-\mathrm{m}^{2}$ random quadrats per plot three times by manually harvesting. Harvested grain was dried to constant weight and weighed. Yield per plot was adjusted to $13.5 \%$ moisture content.

\subsubsection{Soil Water Content and Storage}

An aluminum access tube (45-mm internal diameter) was installed $1.3 \mathrm{~m}$ deep between rows near the center of each plot prior to sowing. The soil volumetric water content $\left(\mathrm{m}^{3} / \mathrm{m}^{3}, \%\right)$ was monitored using a local field-calibrated CNC503B Neutron Moisture Probe (Super Energy Nuclear Technology, Ltd., Beijing, China) at 10-cm intervals from 10 to $120 \mathrm{~cm}$ below the soil surface at GS01, GS24, GS35, GS44, GS49, GS71, GS80, and GS91.

$$
\text { Soil water storage }(\mathrm{mm})=\sum\left(\Delta \theta_{i} \times Z_{i}\right)
$$

where $\Delta \theta_{i}$ is the volumetric water content in a certain soil layer, $Z_{i}$ is the depth of the soil layer $(\mathrm{mm})$, and $i$ is the soil layer [12].

\subsubsection{Calculation of Evapotranspiration}

The evapotranspiration was computed using climate data obtained from the Tai'an Agrometeorological Experimental Station with the following Equations [6]:

$$
\text { Evapotranspiration }(\mathrm{mm})=\Delta W+I+R-P-S R
$$

where $\Delta W$ is the change in the soil water storage for 1.2- $\mathrm{m}$ soil depth ( $\mathrm{mm}$ ) [32], which is also defined as the seasonal soil water depletion $(\mathrm{mm})$ [27], $I$ is the irrigation amount $(\mathrm{mm}), R$ is the rainfall $(\mathrm{mm})$, $P$ is the percolation $(\mathrm{mm})$, and $S R$ is the surface runoff $(\mathrm{mm}) . P$ was estimated using the approach 
proposed by Zhou et al. [17]. Due to the foundation of plots, no big rain events occurred during the experimental period, resulting in negligible $S R$.

$$
P=W i-F C
$$

where $W i$ is the water stored in the $i$ soil layer ( $i$ soil depth multiplied by soil water content, $\mathrm{mm}$ ) and $F C$ is the field capacity $(\mathrm{mm})$.

\subsubsection{Water Use Efficiency}

Water use efficiency was calculated using the following Equation [5]

$$
\text { WUE }=\text { Yield/Evapotranspiration }
$$

where Yield is the grain yield $\left(\mathrm{g} \mathrm{m}^{-2}\right)$ of the crops, and Evapotranspiration is the total amount of evapotranspiration $(\mathrm{mm})$ during the whole growing season of winter wheat.

\subsection{Statistical Analyses}

All figures were plotted using SigmaPlot version 12.5 (SPSS Inc., Chicago, IL, USA). Data were analyzed with SAS 9.2 software (SAS Institute Inc., Cary, NC, USA) using the FIXED model via ANOVA. The means were considered significant with the least significant difference test at $p \leq 0.05$.

\section{Results}

\subsection{Soil Water Content at Different Soil Layers at GS35, GS49, and GS71}

The soil water content $\left(\mathrm{m}^{3} / \mathrm{m}^{3}, \%\right)$ was progressively increased with increasing the soil depth at GS49 and GS71 under W1 and W2 treatments, whereas in W3 it hardly decreased in the middle soil layer in the 2014-2016 growing seasons (Figure 4). The soil water content had a similar ' $Z$ '-shaped curve change at GS35 and GS49 in the 2014-2016 growing seasons. Significant difference between soil water content and soil layer was detected. The soil layer of $0-10 \mathrm{~cm}$ had the lowest soil water content at all the growth stages, and then soil water content gradually increased with the increasing soil depth from 0 to $30 \mathrm{~cm}$. At GS35 and GS49, the soil water content gradually declined, followed by the soil depth increment from 30 to $80 \mathrm{~cm}$ when the W1 was applied. At the same time, the soil water content at GS35 significantly decreased with the increasing soil layer from 40 to $100 \mathrm{~cm}$ under the W2 and W3 as well as the soil water content at GS49 under W3; whereas, the soil water content at other soil layers, besides the above, especially for that at GS71 progressively increased with increasing the soil depth. These results indicated that the soil layer from 30 to $80 \mathrm{~cm}$ might be the main water-absorption area for winter wheat, which could be deepened under limited water or increasing irrigation amount up to the soil layer from 40 to $100 \mathrm{~cm}$. Vegetative growth of winter wheat could require more water than reproductive growth as there was almost no decline for the soil water content of different soil layers at GS71 under irrigation condition. 


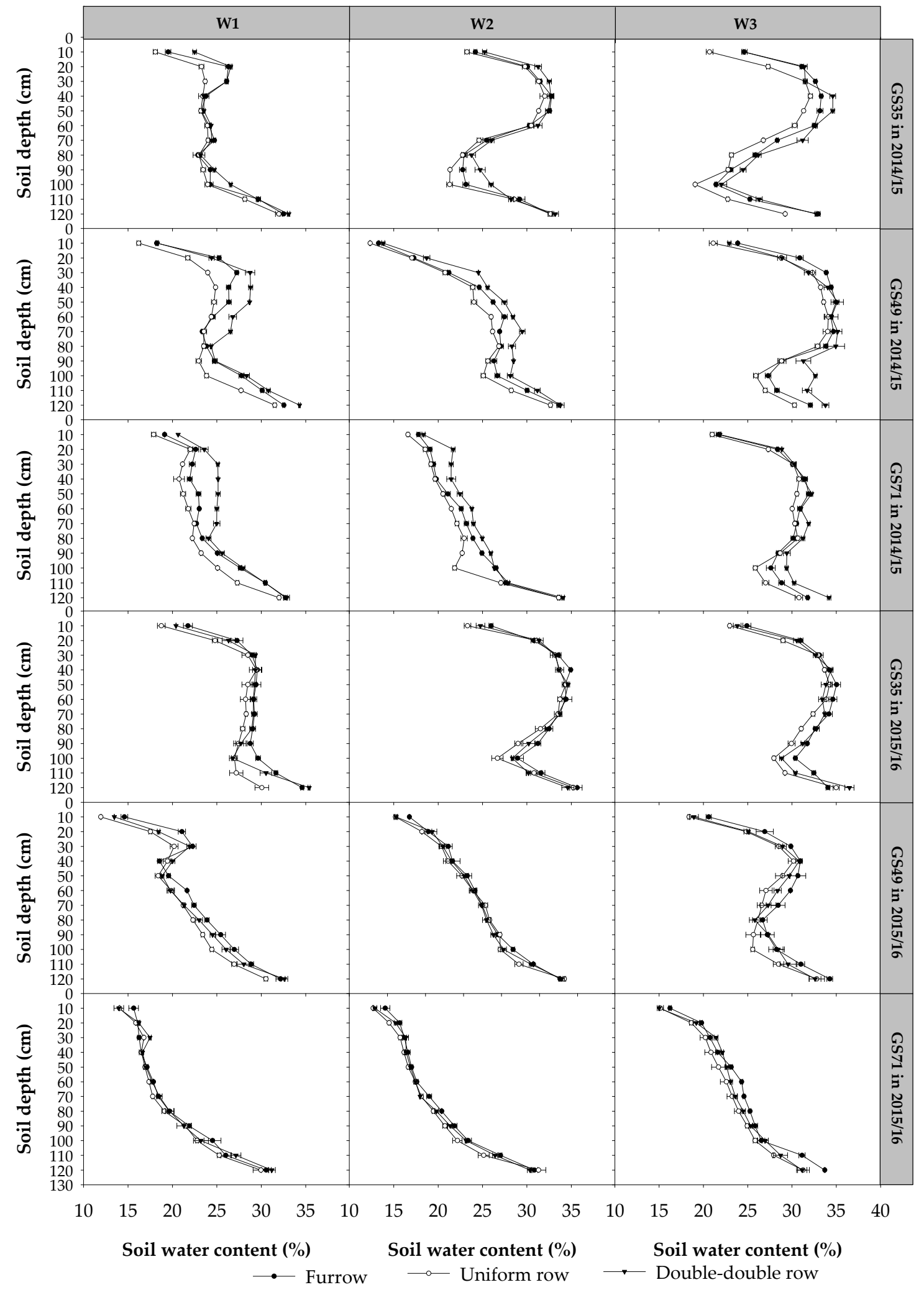

Figure 4. Effects of planting modes and irrigation on the soil water content in 0-120-cm soil layers. W1, irrigation $50 \mathrm{~mm}$ water each at growth stage 34 (GS34) and GS48; W2, irrigation $100 \mathrm{~mm}$ water at GS48; and W3, irrigation $100 \mathrm{~mm}$ water each at GS34 and GS48. The bars are the standard error.

The DD in 2014/15 and F in 2015/16 resulted in an increase of soil water content compared with $\mathrm{U}$. The ranking based on the average soil water content for the two growing seasons was DD $>\mathrm{F}>\mathrm{U}$. 
The average soil water content of W1, W2, and W3 was $25.0 \%, 25.5 \%$, and $29.6 \%$ in 2014/15 and 23.4\%, $24.4 \%$, and $27.7 \%$ in $2015 / 16$, respectively, indicating that the soil water content increased with an increasing irrigation amount, which in 2014/15 was higher than that in 2015/16. Additionally, the variance analysis indicated that there was a significant increment in soil water content for plants in W3 compared with that in W1 and no significant difference in soil water content between W1 with W2 at GS49 and GS71 even though the soil water content of W1 was lower than that of W2. Years, interactions for years $\times$ irrigation, years $\times$ planting mode, and years $\times$ irrigation $\times$ planting mode significantly influenced soil water content at GS35, GS49, and GS71 besides the effect for the years $\times$ irrigation interaction on soil water content at GS35 (Table 3).

Table 3. Analysis of variance (ANOVA; $p$-values) for soil water content of winter wheat at growth stage 35 (GS35), GS49 and GS71.

\begin{tabular}{ccccccc}
\hline \multirow{2}{*}{$\begin{array}{c}\text { Source of Variation } \\
\boldsymbol{P}>\mathbf{F}\end{array}$} & \multicolumn{2}{c}{ GS35 } & \multicolumn{2}{c}{ GS49 } & \multicolumn{2}{c}{ GS71 } \\
\cline { 2 - 6 } & $\mathbf{2 0 1 4 / \mathbf { 1 5 }}$ & $\mathbf{2 0 1 5 / 1 6}$ & $\mathbf{2 0 1 4 / \mathbf { 1 5 }}$ & $\mathbf{2 0 1 5 / 1 6}$ & $\mathbf{2 0 1 4 / \mathbf { 1 5 }}$ & $\mathbf{2 0 1 5 / 1 6}$ \\
\hline Irrigation & 0.0001 & 0.0001 & 0.0001 & 0.0001 & 0.0001 & 0.0001 \\
Planting mode (PM) & 0.0001 & 0.0001 & 0.0001 & 0.0001 & 0.0001 & 0.0001 \\
Irrigation $\times$ PM & 0.0002 & 0.2104 & 0.0001 & 0.0041 & 0.0087 & 0.0314 \\
Years & \multicolumn{2}{c}{0.0001} & 0.0001 & 0.0001 \\
Years $\times$ Irrigation & \multicolumn{2}{c}{0.2778} & 0.0001 & 0.0001 \\
Years $\times$ PM & 0.0001 & 0.0001 & 0.0001 \\
Years $\times$ Irrigation $\times$ PM & 0.0024 & 0.0001 & 0.0066 \\
\hline
\end{tabular}

\subsection{Soil Water Content during the Whole Growing Season of Winter Wheat}

The soil water content decreased with growth stage development (Figure 5). There was no significant difference between soil water contents of different planting modes at GS01. The largest decrease from GS01 to GS91 in 2014-2016 season occurred due to the plentiful soil water content at sowing and deficit irrigation and rainfall in the later growing stages of the winter wheat. The soil water content increased immediately after irrigation but declined rapidly after the peak value because of the increasing crop water requirement with growth development. Table 4 shows that planting pattern and irrigation had significant effects on soil water content, whereas no significant difference in soil water content was found in the interactions for planting mode $\times$ irrigation and years $\times$ irrigation. The soil water content of $U$ was significantly lower than those of DD and F. The DD planting had the highest soil water content in 2014/15; in contrast, the soil water content of F was significantly higher than that of DD in 2015/16. DD resulted in more soil water than F based on the average soil water content of two years. The average soil water contents of W1, W2, and W3 were $24.0 \%, 24.1 \%$, and $26.8 \%$ in $2014 / 15$, and $23.4 \%, 24.1 \%$, and $25.9 \%$ in $2015 / 16$, respectively. Under the same planting mode, the average seasonal soil water content of DD in W3 was increased by 10.8\% in 2014/15 and 10.7\% in $2015 / 16$ as compared with that in W1 and, similarly, F in W3 improved soil water content by $9.5 \%$ in 2014/15 and 11.1\% in 2015/16 than F in W1. Moreover, the interaction between years, planting mode, and irrigation significantly influenced the soil water content (Table 4), but the soil water content of W1 was not significantly different from that of W2. The data showed that reasonable planting mode with high irrigation amounts and rainfall were beneficial to improving soil water content. 


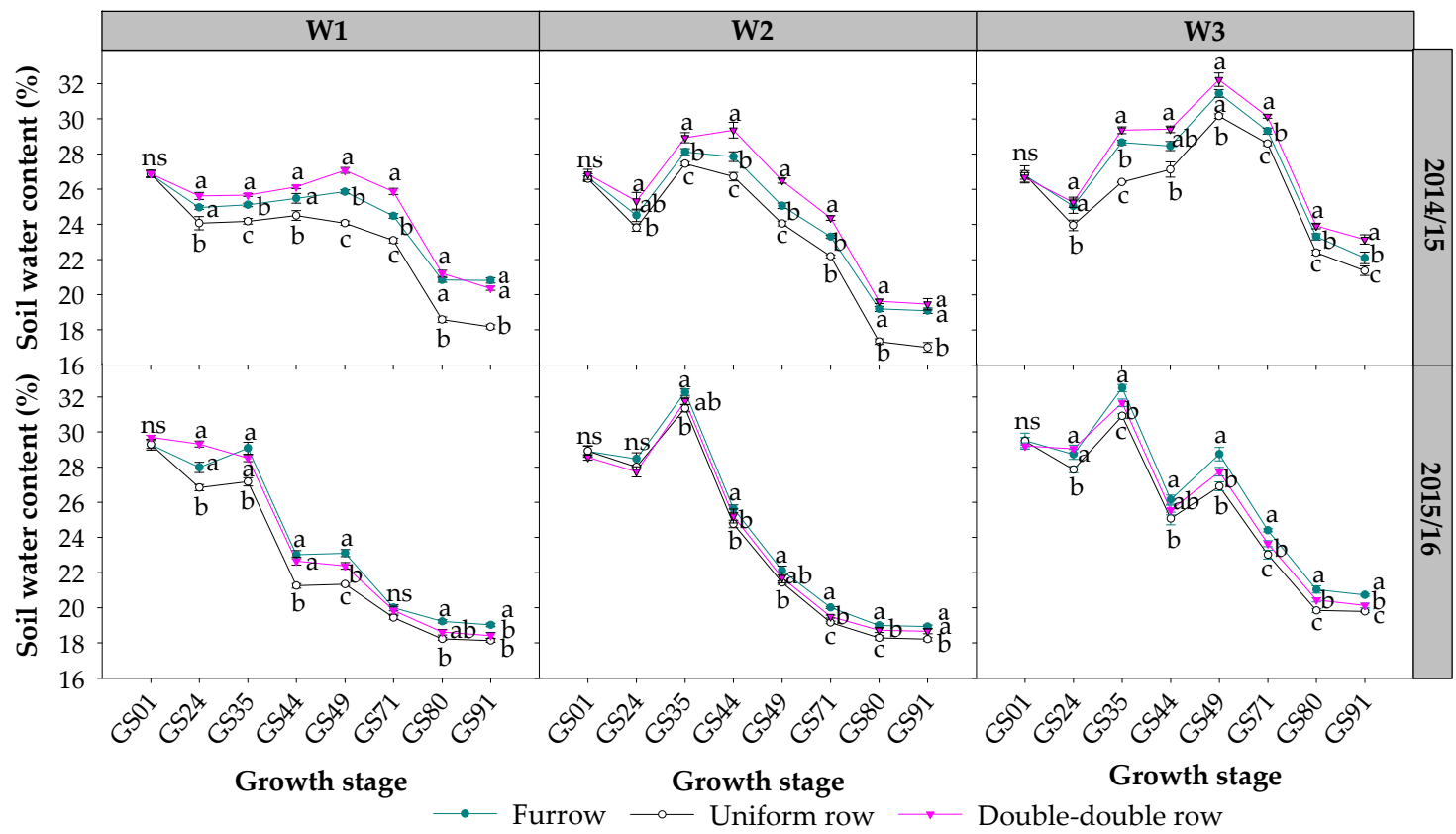

Figure 5. Effects of planting modes and irrigation on the soil water content during the growing season. $\mathrm{W} 1$, irrigation $50 \mathrm{~mm}$ water each at growth stage 34 (GS34) and GS48; W2, irrigation $100 \mathrm{~mm}$ water at GS48; and W3, irrigation $100 \mathrm{~mm}$ water each at GS34 and GS48; ns, not significantly different $(p>0.05)$, triangle and circular symbols followed by the same letter are not significantly different according to the least significant difference at 0.05 .

Table 4. Analysis of variance (ANOVA; $p$-values) for soil water content and soil water storage of winter wheat in the whole growing season.

\begin{tabular}{|c|c|c|c|c|}
\hline \multirow{2}{*}{$\begin{array}{l}\text { Source of Variation } \\
\qquad P>F\end{array}$} & \multicolumn{2}{|c|}{ Soil Water Content (\%) } & \multicolumn{2}{|c|}{ Soil Water Storage $(\mathrm{mm})$} \\
\hline & $2014 / 15$ & $2015 / 16$ & $2014 / 15$ & $2015 / 16$ \\
\hline Irrigation & 0.0056 & 0.0057 & 0.0069 & 0.0065 \\
\hline Planting mode (PM) & 0.0001 & 0.0001 & 0.0001 & 0.0001 \\
\hline Irrigation $\times \mathrm{PM}$ & 0.8359 & 0.0499 & 0.7094 & 0.0164 \\
\hline Years & \multicolumn{2}{|c|}{0.0001} & \multicolumn{2}{|c|}{0.3671} \\
\hline Years $\times$ Irrigation & \multicolumn{2}{|c|}{0.2778} & \multicolumn{2}{|c|}{0.8745} \\
\hline Years $\times$ PM & \multicolumn{2}{|c|}{0.0001} & \multicolumn{2}{|c|}{0.0001} \\
\hline Years $\times$ Irrigation $\times \mathrm{PM}$ & \multicolumn{2}{|c|}{0.0024} & \multicolumn{2}{|c|}{0.5888} \\
\hline
\end{tabular}

\subsection{Soil Water Storage at Different Growth Stages}

The soil water storage of 0-120-cm soil depth was $300.2 \mathrm{~mm}$ in 2014/15 and $293.2 \mathrm{~mm}$ in 2015/16, respectively, and there was no obvious difference between the two growing seasons (Figure 6). The soil water storage increased immediately after irrigation, and the peak values appeared at GS35 under all irrigation treatments and at GS49 under W1 and W3. However, the peak was not observed for the W1 treatment because of high water requirements for winter wheat from booting to the inflorescence emergence stage under small irrigation amounts applied. The change trend of soil water storage during the growing season was similar to that of soil water content. Years $\times$ planting mode interaction had significant effect on soil water content (Table 4), with the soil water storage in the three planting modes in the following order DD $>\mathrm{F}>\mathrm{U}$. The difference between soil water storage in different planting modes was higher in 2014/15 than that in 2015/16, indicating that DD could maintain more soil water storage than F at deficit water. The average soil water storage of W1, W2, and W3 was $289.6 \mathrm{~mm}$, $289.6 \mathrm{~mm}$, and $321.3 \mathrm{~mm}$ in 2014/15 and $280.9 \mathrm{~mm}, 288.1 \mathrm{~mm}$, and $310.5 \mathrm{~mm}$ in 2015/16, respectively (Figure 6). The W3 resulted in a significant increase of soil water storage than W1 and W2, while there 
was no significant difference between soil water storage of W1 and W2. Under the same irrigation frequency, increasing irrigation amount enhanced by $8.9 \%$ for DD and $11.1 \%$ for F. In addition, no significant difference in soil water storage was found in the years $x$ irrigation and years $\times$ irrigation $\times$ planting mode interactions (Table 4). All data showed that planting mode contributed to more soil water storage for winter wheat as compared with irrigation schedules.

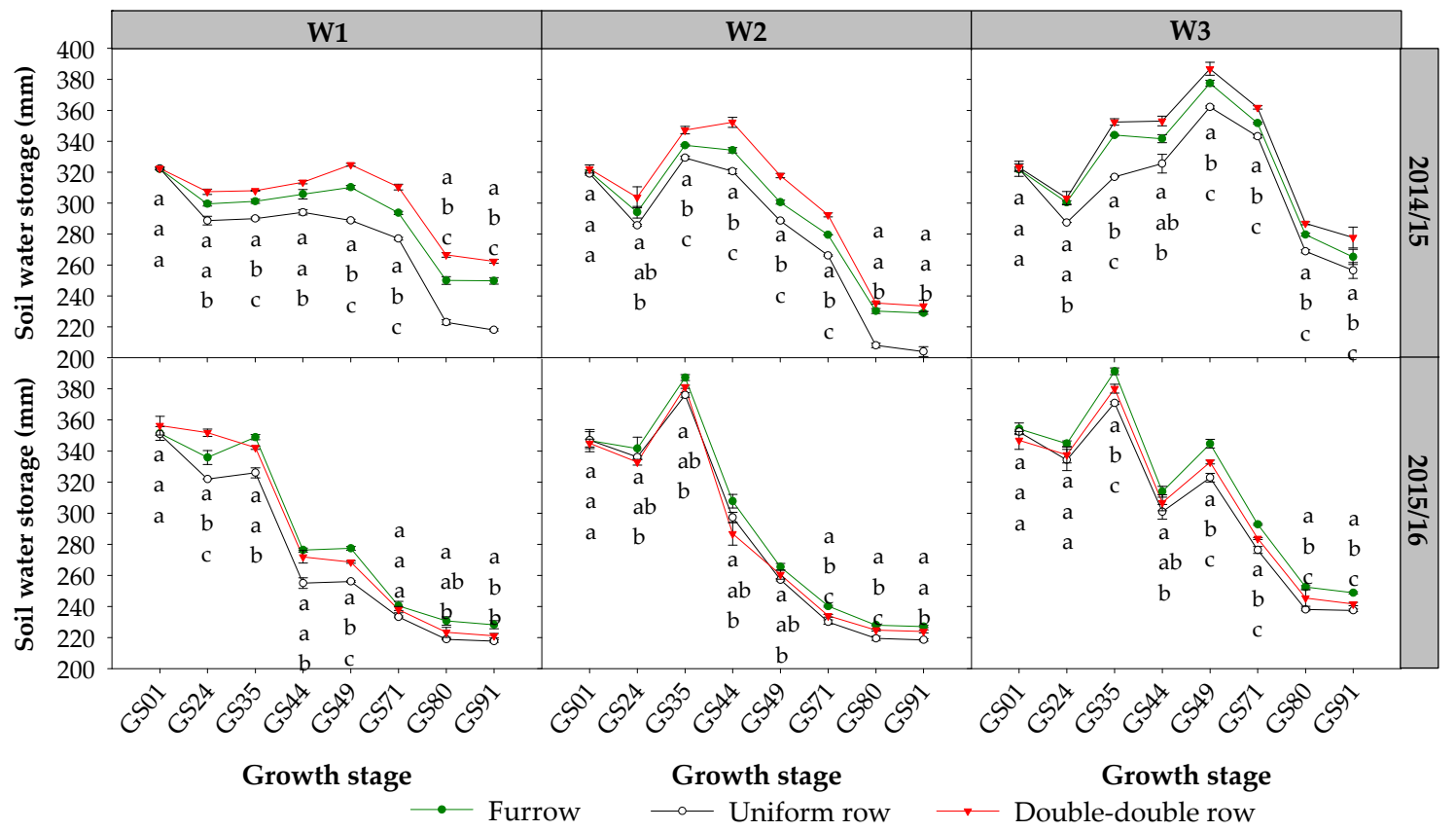

Figure 6. Effects of planting modes and irrigation on soil water storage during the growing season. W1, irrigation $50 \mathrm{~mm}$ water each at growth stage 34 (GS34) and GS48; W2, irrigation $100 \mathrm{~mm}$ water at GS48; and W3, irrigation $100 \mathrm{~mm}$ water each at GS34 and GS48. The same letters are not significantly different according to the least significant difference at 0.05 . The bars are the standard error.

\subsection{Evapotranspiration during Different Growth Stages}

The evapotranspiration of different planting modes during GS01-GS24 was higher than GS24-GS35, which may be due to high evaporation under low-covered and bare soil, although there was no irrigation in this period (Table 5). There was a relatively high evapotranspiration at GS24-GS35 because irrigation was applied at GS34. However, when the irrigation was applied at GS48, the evapotranspiration at GS49-GS71 was lower than that at GS35-GS44, and especially the lowest evapotranspiration of W2, which might have been related to the large water absorption for the rapid growth of winter wheat. In 2014/15, DD produced less evapotranspiration than F and U, but the evapotranspiration of DD was not significantly different from that of $\mathrm{F}$. The average evapotranspiration of six growth stages for W1, W2, and W3 was $55.9 \mathrm{~mm}, 59.4 \mathrm{~mm}$, and $69.8 \mathrm{~mm}$, respectively, and, compared with the evapotranspiration of $\mathrm{W} 1$, the evapotranspirations of $\mathrm{W} 3$ and $\mathrm{W} 2$ were improved by $24.9 \%$ and $6.3 \%$, respectively. W3 significantly improved evapotranspiration compared with W1. In 2015/16, the significant differences between treatments were noted where DD applied in winter wheat resulted in the lowest evapotranspiration. The average evapotranspiration of six growth stages for W1, W2, and W3 was $68.5 \mathrm{~mm}, 67.3 \mathrm{~mm}$, and $82.6 \mathrm{~mm}$, respectively, and W3 evaporated more water, by $22.7 \%$, than W2. There was no significant difference between evapotranspiration of W1 and W2, indicating that increasing irrigation frequency would not significantly enhance evapotranspiration. The interaction analysis for years, irrigation, and planting mode showed that the irrigation schedules might contribute more toward evapotranspiration of winter wheat than planting mode. Grain yield was significantly positively correlated with evapotranspiration from GS01 to GS71, indicating that the evapotranspiration at different growth stages had beneficial effect on grain yield over both years. 
Table 5. Effects of planting mode (PM) and irrigation on the evapotranspiration ( $\mathrm{mm})$ at different stages of winter wheat growth in 2014-2016.

\begin{tabular}{|c|c|c|c|c|c|c|c|}
\hline Irrigation & PM & GS01-GS24 & GS24-GS35 & GS35-GS44 & GS44-GS49 & GS49-GS71 & GS71-GS91 \\
\hline \multicolumn{8}{|c|}{$2014 / 2015$} \\
\hline \multirow{3}{*}{ W1 } & $\mathrm{U}$ & $81.4 \mathrm{a}$ & $51.1 \mathrm{a}$ & $66.1 \mathrm{a}$ & $55.5 \mathrm{a}$ & $48.6 \mathrm{~b}$ & $59.0 \mathrm{a}$ \\
\hline & DD & $63.1 \mathrm{c}$ & $49.7 \mathrm{a}$ & $64.6 \mathrm{a}$ & $39.0 \mathrm{c}$ & $51.2 \mathrm{ab}$ & $48.1 \mathrm{~b}$ \\
\hline & $\mathrm{F}$ & $69.9 b$ & $50.7 \mathrm{a}$ & $64.9 \mathrm{a}$ & $45.8 \mathrm{~b}$ & $53.3 \mathrm{a}$ & $44.0 \mathrm{~b}$ \\
\hline \multirow{3}{*}{ W2 } & $\mathrm{U}$ & $82.2 \mathrm{a}$ & $58.8 \mathrm{a}$ & $78.8 \mathrm{a}$ & $32.3 \mathrm{a}$ & $59.2 \mathrm{ab}$ & $67.9 \mathrm{a}$ \\
\hline & $\mathrm{DD}$ & $66.1 \mathrm{c}$ & $51.8 \mathrm{~b}$ & $65.0 \mathrm{c}$ & $34.8 \mathrm{a}$ & $62.3 \mathrm{a}$ & $65.2 \mathrm{a}$ \\
\hline & $\mathrm{F}$ & $72.1 \mathrm{~b}$ & $53.7 \mathrm{~b}$ & $71.2 \mathrm{~b}$ & $33.8 \mathrm{a}$ & $57.9 \mathrm{~b}$ & $56.3 \mathrm{~b}$ \\
\hline \multirow{3}{*}{ W3 } & $\mathrm{U}$ & $81.5 \mathrm{a}$ & $72.9 \mathrm{a}$ & $68.3 \mathrm{~b}$ & $71.3 \mathrm{a}$ & $57.4 \mathrm{a}$ & $98.1 \mathrm{a}$ \\
\hline & $\mathrm{DD}$ & $69.8 \mathrm{~b}$ & $53.2 \mathrm{c}$ & $66.1 \mathrm{~b}$ & $62.1 \mathrm{a}$ & $58.7 \mathrm{a}$ & $89.9 \mathrm{~b}$ \\
\hline & F & $68.1 \mathrm{~b}$ & $58.9 \mathrm{~b}$ & $72.4 \mathrm{a}$ & $64.5 \mathrm{~b}$ & $60.3 \mathrm{a}$ & $82.7 \mathrm{c}$ \\
\hline \multicolumn{8}{|c|}{ Source of variance } \\
\hline \multicolumn{2}{|c|}{ Irrigation } & 0.5734 & 0.0001 & 0.0006 & 0.0008 & 0.0005 & 0.0001 \\
\hline \multicolumn{2}{|c|}{ PM } & 0.0001 & 0.0001 & 0.0001 & 0.0072 & 0.0356 & 0.0001 \\
\hline \multicolumn{2}{|c|}{ Irrigation $\times \mathrm{PM}$} & 0.00829 & 0.0001 & 0.0001 & 0.0308 & 0.0395 & 0.0002 \\
\hline \multicolumn{8}{|c|}{$2015 / 2016$} \\
\hline \multirow{3}{*}{ W1 } & $\mathrm{U}$ & $116.4 \mathrm{a}$ & $88.3 \mathrm{~b}$ & $77.9 \mathrm{a}$ & $54.1 \mathrm{a}$ & $55.6 \mathrm{c}$ & $20.4 \mathrm{a}$ \\
\hline & $\mathrm{DD}$ & $103.6 \mathrm{~b}$ & $97.7 \mathrm{a}$ & $77.9 \mathrm{a}$ & $55.7 \mathrm{a}$ & $63.4 \mathrm{~b}$ & $21.6 \mathrm{a}$ \\
\hline & $\mathrm{F}$ & $106.4 \mathrm{~b}$ & $79.2 \mathrm{c}$ & $77.5 \mathrm{a}$ & $51.3 \mathrm{~b}$ & $67.5 \mathrm{a}$ & $16.9 \mathrm{~b}$ \\
\hline \multirow{3}{*}{ W2 } & $\mathrm{U}$ & $106.6 \mathrm{a}$ & $102.4 \mathrm{a}$ & $88.2 \mathrm{a}$ & $42.5 \mathrm{ab}$ & $60.0 \mathrm{a}$ & $17.5 \mathrm{ab}$ \\
\hline & $\mathrm{DD}$ & $101.9 \mathrm{ab}$ & $93.8 \mathrm{~b}$ & $87.9 \mathrm{a}$ & $44.1 \mathrm{a}$ & $59.3 \mathrm{a}$ & $14.8 \mathrm{~b}$ \\
\hline & $\mathrm{F}$ & $108 \mathrm{~b}$ & $88.2 \mathrm{c}$ & $86.8 \mathrm{a}$ & $40.3 \mathrm{~b}$ & $58.1 \mathrm{a}$ & $17.8 \mathrm{a}$ \\
\hline \multirow{3}{*}{ W3 } & $\mathrm{U}$ & $113.8 \mathrm{a}$ & 115.9 a & $80.5 \mathrm{a}$ & $78.5 \mathrm{a}$ & $83.6 \mathrm{a}$ & $46.0 \mathrm{a}$ \\
\hline & $\mathrm{DD}$ & $105.0 \mathrm{~b}$ & $99.7 \mathrm{~b}$ & $80.3 \mathrm{a}$ & $73.2 \mathrm{~b}$ & $81.9 \mathrm{a}$ & $47.0 \mathrm{a}$ \\
\hline & $\mathrm{F}$ & $105.2 \mathrm{~b}$ & $99.1 \mathrm{~b}$ & $80.6 \mathrm{a}$ & $65.8 \mathrm{c}$ & $81.4 \mathrm{a}$ & $48.9 \mathrm{a}$ \\
\hline \multicolumn{8}{|c|}{ Source of variation } \\
\hline \multicolumn{2}{|c|}{ Irrigation } & 0.0678 & 0.0001 & 0.0002 & 0.0001 & 0.0001 & 0.0001 \\
\hline \multicolumn{2}{|c|}{ PM } & 0.0001 & 0.0001 & 0.5332 & 0.0002 & 0.0201 & 0.9866 \\
\hline \multicolumn{2}{|c|}{ Irrigation $\times \mathrm{PM}$} & 0.2758 & 0.0001 & 0.7236 & 0.0111 & 0.0001 & 0.0247 \\
\hline \multicolumn{2}{|c|}{ Years $\times$ Irrigation } & 0.0120 & 0.0659 & 0.0001 & 0.6298 & 0.0001 & 0.0001 \\
\hline \multicolumn{2}{|c|}{ Years $\times$ PM } & 0.0324 & 0.4799 & 0.0772 & 0.3722 & 0.9823 & 0.0058 \\
\hline \multicolumn{2}{|c|}{$\begin{array}{c}\text { Years } \times \text { Irrigation } \times \\
\text { PM }\end{array}$} & 0.9814 & 0.0001 & 0.0147 & 0.0337 & 0.0124 & 0.0016 \\
\hline \multicolumn{2}{|c|}{$R$} & $0.4716^{*}$ & 5224 * & 0.3666 & 0.5733 * & 0.8112 ** & -0.0117 \\
\hline
\end{tabular}

* W1, irrigation $50 \mathrm{~mm}$ water each at growth stage 34 (GS34) and GS48; W2, irrigation $100 \mathrm{~mm}$ water at GS48; and W3, irrigation $100 \mathrm{~mm}$ water at GS34 and GS48, respectively; $\mathrm{U}$, uniform row planting; DD, double-double row planting; F, furrow-ridge row planting; PM, planting modes. Values followed by different letters at the same column in the table are significant differences according to the least significant difference at 0.05 . $R$ was the correlation coefficient between evapotranspiration at different stages and yield; * means $p<0.05$; ${ }^{* *}$ means $p<0.01$.

\subsection{Yield, Water Use Efficiency, Seasonal Soil Water Depletion, and Evapotranspiration}

Years, irrigation, planting mode, and their interactions between years, irrigation, and planting mode had significant effects on grain yield, soil water depletion, evapotranspiration, and WUE, leading to the significant differences between yield, soil water depletion, evapotranspiration, and WUE between 
two years (Table 6). The average soil water depletion and evapotranspiration in two years in W1 was lower than those in W2, but there was no significant difference between those of W1 and W2. When the irrigation amount increased, the soil water depletion significantly declined while evapotranspiration significantly increased in W3 compared with those in W1 and W2. The contribution of soil water depletion to evapotranspiration in two years was $26.4 \%$ for $\mathrm{W} 1,28.0 \%$ for $\mathrm{W} 2$, and $18.3 \%$ for $\mathrm{W} 3$, indicating that soil water depletion contributed greatly to the seasonal evapotranspiration under deficit water. Additionally, compared with U, the DD and F planting patterns resulted in less soil water depletion and evapotranspiration, which contributed $22.8 \%$ and $23.5 \%$ of soil water depletion to evapotranspiration, respectively. Meanwhile, the evapotranspiration and soil water depletion of DD was relatively lower than that of F in 2014/15 and, to the contrary, the lowest evapotranspiration in F in 2015/16, but there was no significant difference between those of DD and F.

Table 6. Effects of planting mode and irrigation on the yield, soil water depletion, evapotranspiration, and water use efficiency (WUE) during the growing season of winter wheat growth in 2014-2016.

\begin{tabular}{|c|c|c|c|c|c|c|c|c|}
\hline \multirow{2}{*}{ Treatments } & \multicolumn{2}{|c|}{ Yield $\left(\mathrm{g} \mathrm{m}^{-2}\right)$} & \multicolumn{2}{|c|}{$\begin{array}{c}\text { Soil Water } \\
\text { Depletion }(\mathrm{mm})\end{array}$} & \multicolumn{2}{|c|}{$\begin{array}{c}\text { Evapotranspiration } \\
(\mathrm{mm})\end{array}$} & \multicolumn{2}{|c|}{ WUE $\left(\mathrm{g} \mathrm{m}^{-2} \mathrm{~mm}^{-1}\right)$} \\
\hline & $2014 / 15$ & $2015 / 16$ & $2014 / 15$ & $2015 / 16$ & $2014 / 15$ & $2015 / 16$ & $2014 / 15$ & $2015 / 16$ \\
\hline \multicolumn{9}{|l|}{ Irrigation (mm) } \\
\hline W1 & $755 \mathrm{~b}$ & $823 \mathrm{~b}$ & $78.8 \mathrm{~b}$ & $126.7 \mathrm{a}$ & $344.0 \mathrm{c}$ & $421.1 \mathrm{~b}$ & $2.20 \mathrm{a}$ & $1.93 \mathrm{a}$ \\
\hline W2 & $726 c$ & $771 \mathrm{c}$ & $98.2 \mathrm{a}$ & $121.1 \mathrm{a}$ & $363.4 \mathrm{~b}$ & $415.5 \mathrm{~b}$ & $2.00 \mathrm{~b}$ & $1.86 \mathrm{~b}$ \\
\hline W3 & $804 \mathrm{a}$ & 991 a & $55.9 \mathrm{c}$ & $108.5 \mathrm{~b}$ & $421.1 \mathrm{a}$ & $502.9 \mathrm{a}$ & $1.91 \mathrm{~b}$ & $1.98 \mathrm{a}$ \\
\hline \multicolumn{9}{|l|}{ Planting mode (PM) } \\
\hline Uniform row & $763 \mathrm{~b}$ & $767 c$ & $95.0 \mathrm{a}$ & $121.7 \mathrm{a}$ & $393.5 \mathrm{a}$ & $449.4 \mathrm{a}$ & $1.95 \mathrm{~b}$ & $1.71 \mathrm{c}$ \\
\hline Double-double row & 802 a & $878 \mathrm{~b}$ & $64.7 \mathrm{c}$ & $\begin{array}{c}118.6 \\
\mathrm{ab}\end{array}$ & $363.2 \mathrm{~b}$ & $\begin{array}{l}446.3 \\
\mathrm{ab}\end{array}$ & $2.23 \mathrm{a}$ & $1.96 \mathrm{~b}$ \\
\hline $\begin{array}{l}\text { Furrow-ridge row } \\
\text { Source of variation }\end{array}$ & $720 c$ & $940 \mathrm{a}$ & $73.2 \mathrm{~b}$ & $116.1 \mathrm{~b}$ & $\begin{array}{l}371.7 \mathrm{~b} \\
>\mathrm{F}\end{array}$ & $443.8 \mathrm{~b}$ & $1.95 \mathrm{~b}$ & $2.13 \mathrm{a}$ \\
\hline Irrigation & 0.0001 & 0.0001 & 0.0001 & 0.0036 & 0.0001 & 0.0001 & 0.0001 & 0.0281 \\
\hline PM & 0.0001 & 0.0001 & 0.0001 & 0.1175 & 0.0001 & 0.3313 & 0.0001 & 0.0001 \\
\hline Irrigation $\times \mathrm{PM}$ & 0.0461 & 0.0181 & 0.0167 & 0.0039 & 0.0178 & 0.0719 & 0.0078 & 0.0001 \\
\hline Years $\times$ Irrigation & \multicolumn{2}{|c|}{0.0001} & \multicolumn{2}{|c|}{0.0135} & \multicolumn{2}{|c|}{0.0135} & \multicolumn{2}{|c|}{0.0001} \\
\hline Years $\times$ PM & \multicolumn{2}{|c|}{0.0001} & \multicolumn{2}{|c|}{0.0002} & \multicolumn{2}{|c|}{0.0002} & \multicolumn{2}{|c|}{0.0001} \\
\hline Years $\times$ Irrigation $\times$ PM & \multicolumn{2}{|c|}{0.0047} & \multicolumn{2}{|c|}{0.0096} & \multicolumn{2}{|c|}{0.0096} & \multicolumn{2}{|c|}{0.0001} \\
\hline
\end{tabular}

W1, irrigation $50 \mathrm{~mm}$ water each at growth stage 34 (GS34) and GS48; W2, irrigation $100 \mathrm{~mm}$ water at GS48; and W3, irrigation $100 \mathrm{~mm}$ water each at GS34 and GS48. Values followed by different letters at the same column in the table are significantly different according to the least significant difference at 0.05 .

The W1 had a significantly increased yield, by $5.5 \%$, and WUE, by $7.0 \%$, relative to W2 under the same volume of water irrigation in the 2014-2016 growing seasons, which might be related to a better distribution of water and a decrease of evapotranspiration during the growing season. For a comparable WUE, there was a significant increment in yield for winter wheat in W3 compared with those in W1 and W2. However, the average WUE in two years did not exceed that in W1 under the same irrigation frequency. Simultaneously, the significant differences in yield and WUE was caused by planting modes in both growing seasons. A contrary variation tendency for yield and WUE in planting modes of $\mathrm{F}$ and DD was found in the 2014-2016 growing seasons; the DD produced the greatest increment of grain yield (by 11.4\%) and WUE (by 14.4\%) compared with F in 2014/15, while F increased yield by $7.1 \%$ and WUE by $8.5 \%$ compared with DD in 2015/16. Two years' results indicated DD had the relatively lower evapotranspiration and soil water depletion and higher grain yield and WUE as compared with F, but no significant differences between them showed. The yield, soil water depletion, evapotranspiration, and WUE in 2015/16 were significantly higher than those in 2014/15 when the higher rainfall occurred in 2015/16. 


\subsection{Relationship Between Yield and Evapotranspiration}

No matter what planting mode was applied, the resulting yield and evapotranspiration had a quadratic dynamic equation (Figure 7). The equations of F, U, and DD planting method were $y$ (yield, $\left.\mathrm{g} \mathrm{m}^{-2}\right)=0.0084 x^{2}-5.3657 x($ evapotranspiration, $\mathrm{mm})+1540.4721\left(R^{2}=0.9918, p<0.0001\right), y=0.0490 x^{2}$ $-38.4889 x+8292.6437\left(R^{2}=0.7544, p=0.0148\right)$, and $y=0.0363 x^{2}-26.4106 x+5559.7574\left(R^{2}=0.9628\right.$, $p<0.0001)$ in 2014/15, respectively, and were $y=0.0126 x^{2}-8.926 x+2397.9326\left(R^{2}=0.8587, p=0.0028\right)$, $y=0.0262 x^{2}-22.862 x+5692.8511\left(R^{2}=0.7842, p=0.0100\right)$, and $y=0.0051 x^{2}-1.7655 x+618.0204$ $\left(R^{2}=0.8772, p=0.0019\right)$ in $2015 / 16$, respectively. The $R$-square values of the equations for all planting modes were significant, showing that dynamic balance was effective and true. High yield might require more evapotranspiration. The evapotranspiration in 2015/16 was higher than that in 2014/15, and yield exhibited a similar change.

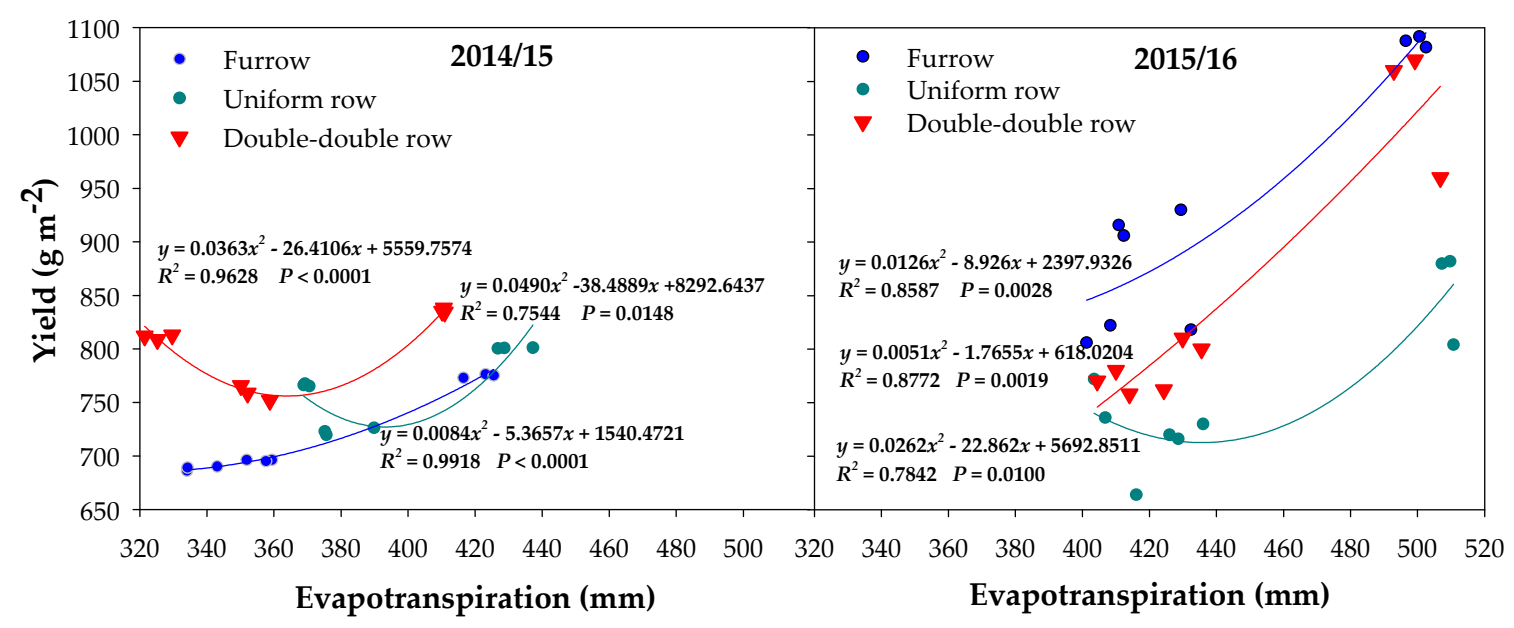

Figure 7. Relationship between yield and evapotranspiration for different planting modes in 2014-2016. The values are the average of replications for each treatment.

\section{Discussion}

Irrigation and planting methods are the two important management practices of any cropping systems that target the balance between environmental resource availability and crop demand $[5,6,13]$. Improper planting patterns can aggravate water scarcity and strongly influence the growth of crops in semiarid regions [33]. Wise use of irrigation and proper planting methods may help to produce more crop per drop [34]. The results from the study also showed that different irrigation amounts and frequency combined with different planting modes affected both grain yield and WUE, demonstrating that optimizing irrigation and planting mode can further improve grain yield and WUE at deficit water in North China Plain.

Quantifying the partitioning of irrigation water during the growing seasons is important for crop development [35]. Water shortages are becoming the most serious threat to the sustainable development of agriculture in the North China Plain [36]. To provide a basis for improving agricultural irrigation management in soils for WUE, it is necessary to accurately estimate the spatial and temporal variations of soil water content, soil water storage, and evapotranspiration [37,38]. The sufficient soil water content at sowing was gradually decreased, even though the irrigation and rainfall supplied because great water consumption occurred at jointing to filling stages to meet the rapid growth development of winter wheat. The similar ' $Z$ '-shaped curve for soil water content at different soil layers showed that the soil layer of $0-80 \mathrm{~cm}$ can be the water-absorbing area for winter wheat as the wheat roots mainly concentrated in the soil layer of $0-80 \mathrm{~cm}$, and especially that the upper soil layer of $0-40 \mathrm{~cm}$ usually contained a large root length density, root weight density, and root surface area density to uptake soil nutrients and water $[13,14,39]$. The deficit irrigation can stimulate roots to grow into deeper soil layers to meet the growth, particularly vegetative growth, of winter wheat, which is 
similar to the reports of Feng et al. [39] and Wang et al. [40]. Additionally, increasing irrigation amount also promotes the absorption for deep water as sufficient water is beneficial to the growth of deep roots. Water absorption for growth and deep percolation led to the water loss [41], which can explain the reason for the reduction of soil water content at 30-80-cm soil layer in the study. The large absorbing area of roots accelerated the dry matter accumulation and then achieved a high grain yield $[39,40]$.

The WUE is affected by grain yield and total evapotranspiration, and traits affecting yield also significantly influenced WUE [6], such as soil water status and evapotranspiration. The moisture contents of soil measured at different growth stages were similar to other findings [42]. The available water at the critical growth stages determines wheat production. In this study, the soil water content and storage in the whole growing season of wheat were affected by planting mode and irrigation. Increment of irrigation amount resulted in a significant increase in soil water content and storage, and then promoted biomass accumulation to achieve high grain yield [17,19]. Nevertheless, low WUE was caused by high evapotranspiration when more irrigation amount was applied. To enhance WUE is the main goal at current severe water shortages' condition [6]. So, the regulated deficit irrigation schedules were applied in the study, including deficit irrigation amount and frequent application of water in small quantities, which not only could relieve wheat of irrigation water shortage problems [43] but also improve irrigation efficiency and crop production [44]. A single irrigation at the jointing stage could reduce irrigation water use compared with full irrigation for winter wheat [28]. The most important period for tiller survival and yield composition of winter wheat is the jointing-to-maturity stage [45]. Li et al. [46] also suggested two times irrigation at jointing and heading stages for developing deficit irrigation regimes of winter wheat in North China Plain. Therefore, when the increment of irrigation frequency at the same irrigation volume was applied in the winter wheat, two times irrigation each at jointing and heading stages that were also used in the study resulted in the significant increment of grain yield by $19.9 \%$ and WUE by $7.1 \%$, benefiting from the decrease of evapotranspiration. A similar study also indicated that frequent application of water in small quantities could increase WUE [47]. The increase in irrigation frequency did not significantly affect soil water content, storage, and depletion, but decreased soil water status, which was contrary to the results of Fang et al. [29]. The transpiration that is usually considered as a productive component for crop production and evaporation that is often regarded as a nonproductive component for crop production [48,49] make up the evapotranspiration. The transpiration generally contributes more than $50 \%$ to evapotranspiration in North China Plain $[5,50]$. Although the increased irrigation frequency suppressed evapotranspiration, it might increase the transpiration rate to make the most of limited water to produce more production. This fact may account for why increasing irrigation frequency increases the grain yield and WUE of winter wheat.

Grain yield was significantly influenced by evapotranspiration as a quadratic dynamic regression relationship was found between yield and evapotranspiration. Yield was reduced from reduction in evapotranspiration under water stress at different crop growth stages [51]. Thus, an increase in yield induced by a decrease or no change in evapotranspiration could help explain the increased WUE under limited precipitation in the North China Plain [52]. Evapotranspiration is the main pathway that water is lost from an ecosystem [53], and its partitioning is crucial for understanding water balance and crop water use strategies, because high evapotranspiration can decrease WUE [54]. The evapotranspiration was composed of soil water depletion, rainfall, and irrigation, where the seasonal rainfall was a constant parameter for evapotranspiration. Thus, it could be seen that soil water depletion, as one variable factor, was important for evapotranspiration under the same irrigation, which was decreased with increasing irrigation, indicating that there was less soil water depletion by wheat under the relatively abundant soil water. The soil water depletion in the experiment contributed approximately $18.3-28.0 \%$ of seasonal evapotranspiration, which was far below the results reported by Fang et al. [29] who found that soil water depletion accounted for $40-60 \%$ of seasonal evapotranspiration under the limited water supply. The reason may be that both the relatively high rainfall in growing season of wheat, which was over $98 \mathrm{~mm}$ higher than that in reports of Fang et al. [29], and supplementary irrigation can 
replenish the soil water consumed and contribute more evaporation to evapotranspiration, as well as reasonable planting mode. The low soil water depletion indicates the soil had relatively abundant soil moisture with less water deficit for wheat no matter what irrigation and planting mode were used. The soil water content and storage at sowing were abundant in our study, which is important for obtaining higher grain yield under deficit water [43]. Although increasing irrigation enhanced soil water content and storage, the loss from evapotranspiration reduced the WUE by $6.1 \%$ at $100-\mathrm{mm}$ irrigation each at jointing and heading stages and by $7.0 \%$ at $100 \mathrm{imm}$ irrigation at jointing stage as compared with 50-mm irrigation each at jointing and heading stages. Consequently, deficit irrigation $50 \mathrm{~mm}$ each at jointing and heading stages can increase WUE and grain yield due to less water depleted by evapotranspiration.

The planting pattern is crucial to influencing the spatial and temporal change in soil water content, and the dynamics of soil water are the key critical zone processes at various spatial scales [55], as shown in Figure 4. The soil water contents of DD and F were higher than that of $U$ planting method during the growing seasons, and then simulated soil water storage, grain yield, and WUE increase. DD may form suitable canopy structure and spatial arrangements [21] that utilize soil water to improve WUE by $14.4 \%$ and grain yield by $11.4 \%$, as DD contributed less soil water depletion to seasonal evapotranspiration compared with those in F in 2014/15. Meanwhile, irrigation and rainfall were collected in the furrow in $\mathrm{F}$, thus enhancing the soil water content and storage; correspondingly, the benefit from the less area for water loss in F reduced evapotranspiration and improved WUE. When both F and DD showed advantage over soil water status, WUE, and yield, comparison between F and DD appeared to be particularly important for selecting the optimal planting mode for winter wheat. Even though DD had no significant difference from $\mathrm{F}$ in every trait, DD can maintain relatively higher soil water status, grain yield, and WUE with less evapotranspiration and soil water depletion compared with $\mathrm{F}$ in two years when more severe water deficit condition occurred. Additionally, DD can save more manpower, material resources, and financial resources to pursue maximum economic benefits than $\mathrm{F}$ that is hard to plant and govern. Thus, DD would be easier and more profitable for a producer to plant in a large area in the region. Synthesizing every aspect, DD was selected to be the best and most rational planting mode for winter wheat to improve yield and WUE at water shortage region.

Soil moisture is generally limited by drought stress and has a direct effect on the growth of wheat, resulting in decreased and unsustainable yield production [56]. With optimized irrigation scheduling, water demand for winter wheat could be reduced by $40-50 \mathrm{~mm}$ without sacrificing yield loss in the North China Plain [57]. Meanwhile, planting mode affected soil water status, grain yield, and WUE, which also needs to be researched thoroughly. Planting mode and irrigation schedules' interaction had a significant effect on grain yield and WUE. Therefore, with freshwater becoming increasingly scarce, the proper irrigation schedules and combined planting modes must be very important for winter wheat at deficit water condition based on the state of the local ecological conditions.

\section{Conclusions}

Irrigation schedules and planting modes affected soil water status, evapotranspiration, WUE, and grain yield in both years. The soil water content had a ' $\mathrm{Z}$ '-shaped curve change trend with increasing soil depth at the booting stage, and the main soil depth for water absorption by winter wheat was found at $0-80 \mathrm{~cm}$ at deficit water. The double-double row planting mode resulted in higher soil water content and storage, which was attributed to a reasonable population structure, and then significantly improved grain yield by $9.7 \%$ and WUE by $12.6 \%$ because of less soil water depletion to seasonal evapotranspiration compared with the traditional uniform planting mode. Although the increased irrigation amount could increase soil water content and storage, soil water depletion, evapotranspiration, and grain yield, WUE was reduced, causing the serious waste of water resources. Irrigating once could increase average soil water content but irrigating twice in small quantities could significantly increase WUE and yield under the same volume of water application in both years. Considering the serious water resources' shortage and economic demand, we suggest that 
the double-double planting mode combined with irrigation $50 \mathrm{~mm}$ each at jointing and heading stages is a good cultivation practice for water-saving technology.

Author Contributions: Conceptualization, X.B.Z. and H.Y.W.; methodology, X.B.Z. and G.Y.W.; formal analysis, X.B.Z., G.Y.W., and L.Y.; investigation, X.B.Z., G.Y.W., and L.Y.; resources, X.B.Z. and H.Y.W.; data curation, X.B.Z.; writing-original draft preparation, X.B.Z. and L.Y.; writing-review and editing, X.B.Z., G.Y.W., and H.Y.W.; supervision, H.Y.W.; funding acquisition, H.Y.W. All authors have read and agreed to the published version of the manuscript.

Funding: The research was funded by the National Natural Science Foundation of China (31760354).

Acknowledgments: We wish to thank Zhang Zhen for help in collecting experimental data.

Conflicts of Interest: The authors declare no conflict of interest.

\section{References}

1. Luo, J.; Shen, Y.; Qi, Y.; Zhang, Y.; Xiao, D. Evaluating water conservation effects due to cropping system optimization on the Beijing-Tianjin-Hebei plain, China. Agric. Syst. 2018, 159, 32-41. [CrossRef]

2. Foulkes, M.J.; Slafer, G.A.; Davies, W.J.; Berry, P.M.; Sylvester-Bradley, R.; Martre, P.; Calderini, D.F.; Griffiths, S.; Reynolds, M.P. Raising yield potential of wheat. III. Optimizing partitioning to grain while maintaining lodging resistance. J. Exp. Bot. 2011, 62, 469-486. [CrossRef] [PubMed]

3. Sacks, W.J.; Deryng, D.; Foley, J.A.; Ramankutty, N. Crop planting dates: An analysis of global patterns. Glob. Ecol. Biogeogr. 2010, 19. [CrossRef]

4. Knapp, A.K.; Briggs, J.M.; Koelliker, J.K. Frequency and extent of water limitation to primary production in a mesic temperate grassland. Ecosystems 2001, 4, 19-28. [CrossRef]

5. Sun, H.; Zhang, X.; Liu, X.; Liu, X.; Shao, L.; Chen, S.; Wang, J.; Dong, X. Impact of different cropping systems and irrigation schedules on evapotranspiration, grain yield and groundwater level in the North China Plain. Agric. Water Manag. 2019, 211, 202-209. [CrossRef]

6. Xu, X.; Zhang, M.; Li, J.; Liu, Z.; Zhao, Z.; Zhang, Y.; Zhou, S.; Wang, Z. Improving water use efficiency and grain yield of winter wheat by optimizing irrigations in the North China Plain. Field Crop. Res. 2018, 221, 219-227. [CrossRef]

7. Pei, H.; Min, L.; Qi, Y.; Liu, X.; Jia, Y.; Shen, Y.; Liu, C. Impacts of varied irrigation on field water budegts and crop yields in the North China Plain: Rainfed vs. irrigated double cropping system. Agric. Water Manag. 2017, 190, 42-54. [CrossRef]

8. Liang, H.; Qin, W.; Hu, K.; Tao, H.; Li, B. Modelling groundwater level dynamics under different cropping systems and developing groundwater neutral systems in the North China Plain. Agric. Water Manag. 2019, 213, 732-741. [CrossRef]

9. Deng, X.-P.; Shan, L.; Zhang, H.; Turner, N.C. Improving agricultural water use efficiency in arid and semiarid areas of China. Agric. Water Manag. 2006, 80, 23-40. [CrossRef]

10. Man, J.; Shi, Y.; Yu, Z.; Zhang, Y. Dry matter production, photosynthesis of flag leaves and water use in winter wheat are affected by supplemental irrigation in the Huang-Huai-Hai Plain of China. PLoS ONE 2015, 10, e0137274. [CrossRef]

11. Blum, A. Effective use of water (EUW) and not water-use efficiency (WUE) is the target of crop yield improvement under drought stress. Field Crop. Res. 2009, 112, 119-123. [CrossRef]

12. Wang, G.; Han, Y.; Zhou, X.; Chen, Y.; Ouyang, Z. Planting pattern and irrigation effects on water-use efficiency of winter wheat. Crop. Sci. 2014, 54, 1166-1174. [CrossRef]

13. Ali, S.; Xu, Y.; Ma, X.; Ahmad, I.; Jia, Q.; Akmal, M.; Hussain, Z.; Arif, M.; Cai, T.; Zhang, J.; et al. Deficit irrigation strategies to improve winter wheat productivity and regulating root growth under different planting patterns. Agric. Water Manag. 2019, 219, 1-11. [CrossRef]

14. Xu, C.; Tao, H.; Tian, B.; Gao, Y.; Ren, J.; Wang, P. Limited-irrigation improves water use efficiency and soil reservoir capacity through regulating root and canopy growth of winter wheat. Field Crop. Res. 2016, 196, 268-275. [CrossRef]

15. Ali, S.; Ma, X.; Jia, Q.; Ahmad, I.; Ahmad, S.; Sha, Z.; Yun, B.; Muhammad, A.; Ren, X.; Shah, S.; et al. Supplemental irrigation strategy for improving grain filling, economic return, and production in winter wheat under the ridge and furrow rainwater harvesting system. Agric. Water Manag. 2019, 226, 105842. [CrossRef] 
16. Zhou, X.B.; Chen, Y.H.; Ouyang, Z. Spacing between rows: Effects on water-use efficiency of double-cropped wheat and soybean. J. Agric. Sci. 2013, 153, 90-101. [CrossRef]

17. Zhang, X.; Kamran, M.; Li, F.; Xue, X.; Jia, Z.; Han, Q. Optimizing fertilization under ridge-furrow rainfall harvesting system to improve foxtail millet yield and water use in a semiarid region, China. Agric. Water Manag. 2020, 227, 105852. [CrossRef]

18. Ghasemi-Aghbolaghi, S.; Sepaskhah, A.R. Barley (Hordeum vulgare L.) response to partial root drying irrigation, planting method and nitrogen application rates. Int. J. Plant Prod. 2018, 12, 13-24. [CrossRef]

19. Jia, Q.; Sun, L.; Ali, S.; Liu, D.; Zhang, Y.; Ren, X.; Zhang, P.; Jia, Z. Deficit irrigation and planting patterns strategies to improve maize yield and water productivity at different plant densities in semi-arid regions. Sci. Rep. 2017, 7, 13881. [CrossRef]

20. Liu, T.; Chen, J.; Wang, Z.; Wu, X.; Wu, X.; Ding, R.; Han, Q.; Cai, T.; Jia, Z. Ridge and furrow planting pattern optimizes canopy structure of summer maize and obtains higher grain yield. Field Crop. Res. 2018, 219, 242-249. [CrossRef]

21. Zhang, Z.; Zhou, X.B.; Chen, Y.H. Effects of irrigation and precision planting patterns on photosynthetic product of wheat. Agron. J. 2016, 108, 2322-2328. [CrossRef]

22. Zhou, X.B.; Yang, L.; Shi, L.B.; Yong, Y.Y. Effect of population horizontal structure and water condition on physiological characteristic and evapotranspiration of winter wheat. Int. J. Agric. Biol. 2019, 22, $263-269$. [CrossRef]

23. Qiu, G.Y.; Wang, L.; He, X.; Zhang, X.Y.; Chen, S.; Chen, J.; Yang, Y. Water use efficiency and evapotranspiration of winter wheat and its response to irrigation regime in the north China plain. Agric. For. Meteorol. 2008, 148, 1848-1859. [CrossRef]

24. Xue, Q.; Zhu, Z.; Musick, J.; Stewart, B.A.; Dusek, D.A. Root growth and water uptake in winter wheat under deficit irrigation. Plant Soil 2003, 257, 151-161. [CrossRef]

25. Fereres, E.; Soriano, M.A. Deficit irrigation for reducing agricultural water use. J. Exp. Bot. 2007, 58, 147-159. [CrossRef]

26. Bian, C.; Ma, C.; Liu, X.; Gao, C.; Liu, Q.; Yan, Z.; Ren, Y.; Li, Q. Responses of winter wheat yield and water use efficiency to irrigation frequency and planting pattern. PLoS ONE 2016, 11, e0154673. [CrossRef]

27. Saliendra, N.Z.; Sperry, J.S.; Comstock, J.P. Influence of leaf water status on stomatal response to humidity, hydraulic conductance, and soil drought in Betula occidentalis. Planta 1995, 196, 357-366. [CrossRef]

28. Zhang, X.; Wang, Y.; Sun, H.; Chen, S.; Shao, L. Optimizing the yield of winter wheat by regulating water consumption during vegetative and reproductive stages under limited water supply. Irrig. Sci. 2013, 31, 1103-1112. [CrossRef]

29. Fang, Q.; Zhang, X.; Shao, L.; Chen, S.; Sun, H. Assessing the performance of different irrigation systems on winter wheat under limited water supply. Agric. Water Manag. 2018, 196, 133-143. [CrossRef]

30. Yuan, Z.; Yan, D.-H.; Yang, Z.-Y.; Yin, J.; Yuan, Y. Temporal and spatial variability of drought in Huang-Huai-Hai River Basin, China. Theor. Appl. Clim. 2015, 122, 755-769. [CrossRef]

31. Zadoks, J.C.; Chang, T.T.; Konzak, C.F. A decimal code for the growth stages of cereals. Weed Res. 1974, 14, 415-421. [CrossRef]

32. Kang, Y.; Wang, F.-X.; Liu, H.; Yuan, B.-Z. Potato evapotranspiration and yield under different drip irrigation regimes. Irrig. Sci. 2004, 23, 133-143. [CrossRef]

33. Chen, H.; Shao, M.; Li, Y. The characteristics of soil water cycle and water balance on steep grassland under natural and simulated rainfall conditions in the Loess Plateau of China. J. Hydrol. 2008, 360, 242-251. [CrossRef]

34. Chen, Z.; Khan, A.; Shi, X.; Hao, X.; Tan, D.K.Y.; Luo, H. Water-nutrient management enhances root morpho-physiological functioning, phosphorus absorption, transportation and utilization of cotton in arid region. Ind. Crop. Prod. 2020, 143, 111975. [CrossRef]

35. Ji, X.-B.; Kang, E.-S.; Chen, R.-S.; Zhao, W.-Z.; Zhang, Z.-H.; Jin, B.-W. A mathematical model for simulating water balances in cropped sandy soil with conventional flood irrigation applied. Agric. Water Manag. 2007, 87, 337-346. [CrossRef]

36. Fang, Q.X.; Ma, L.; Green, T.R.; Yu, Q.; Wang, T.D.; Ahuja, L.R. Water resources and water use efficiency in the North China Plain: Current status and agronomic management options. Agric. Water Manag. 2010, 97, 1102-1116. [CrossRef]

37. Ma, Y.; Feng, S.; Song, X. A root zone model for estimating soil water balance and crop yield responses to deficit irrigation in the North China Plain. Agric. Water Manag. 2013, 127, 13-24. [CrossRef] 
38. Penna, D.; Brocca, L.; Borga, M.; Fontana, G.D. Soil moisture temporal stability at different depths on two alpine hillslopes during wet and dry periods. J. Hydrol. 2013, 477, 55-71. [CrossRef]

39. Feng, S.; Gu, S.; Zhang, H.; Wang, D. Root vertical distribution is important to improve water use efficiency and grain yield of wheat. Field Crop. Res. 2017, 214, 131-141. [CrossRef]

40. Wang, C.; Liu, W.; Li, Q.; Ma, D.-Y.; Lu, H.; Feng, W.; Xie, Y.; Zhu, Y.; Guo, T. Effects of different irrigation and nitrogen regimes on root growth and its correlation with above-ground plant parts in high-yielding wheat under field conditions. Field Crop. Res. 2014, 165, 138-149. [CrossRef]

41. Li, D.; Shao, M. Temporal stability analysis for estimating spatial mean soil water storage and deep percolation in irrigated maize crops. Agric. Water Manag. 2014, 144, 140-149. [CrossRef]

42. Helman, D.; Lensky, I.M.; Bonfil, D.J. Early prediction of wheat grain yield production from root-zone soil water content at heading using Crop RS-Met. Field Crop. Res. 2019, 232, 11-23. [CrossRef]

43. Schlesinger, W.H.; Jasechko, S. Transpiration in the global water cycle. Agric. For. Meteorol. 2014, 189, $115-117$. [CrossRef]

44. Abalos, D.; Sanchez-Martin, L.; Garcia-Torres, L.; Van Groenigen, J.W.; Vallejo, A. Management of irrigation frequency and nitrogen fertilization to mitigate GHG and NO emissions from drip-fertigated crops. Sci. Total. Environ. 2014, 490, 880-888. [CrossRef]

45. Cai, T.; Xu, H.; Peng, D.; Yin, Y.; Yang, W.; Ni, Y.; Chen, X.; Xu, C.; Yang, D.; Cui, Z.; et al. Exogenous hormonal application improves grain yield of wheat by optimizing tiller productivity. Field Crop. Res. 2014, 155, 172-183. [CrossRef]

46. Li, Q.; Dong, B.; Qiao, Y.; Liu, M.; Zhang, J. Root growth, available soil water, and water-use efficiency of winter wheat under different irrigation regimes applied at different growth stages in North China. Agric. Water Manag. 2010, 97, 1676-1682. [CrossRef]

47. Enciso, J.M.; Unruh, B.L.; Colaizzi, P.D.; Multer, W.L. Cotton response to subsurface drip irrigation frequency under deficit irrigation. Appl. Eng. Agric. 2003, 19, 555-558. [CrossRef]

48. Rothfuss, Y.; Biron, P.; Braud, I.; Canale, L.; Durand, J.-L.; Gaudet, J.-P.; Richard, P.; Vauclin, M.; Bariac, T. Partitioning evapotranspiration fluxes into soil evaporation and plant transpiration using water stable isotopes under controlled conditions. Hydrol. Process. 2010, 24, 3177-3194. [CrossRef]

49. Singh, B.-; Eberbach, P.L.; Humphreys, E.; Kukal, S.S. The effect of rice straw mulch on evapotranspiration, transpiration and soil evaporation of irrigated wheat in Punjab, India. Agric. Water Manag. 2011, 98, 1847-1855. [CrossRef]

50. Sun, H.-Y.; Liu, C.-M.; Zhang, X.-Y.; Shen, Y.-J.; Zhang, Y.-Q. Effects of irrigation on water balance, yield and WUE of winter wheat in the North China Plain. Agric. Water Manag. 2006, 85, 211-218. [CrossRef]

51. Geerts, S.; Raes, D. Deficit irrigation as an on-farm strategy to maximize crop water productivity in dry areas. Agric. Water Manag. 2009, 96, 1275-1284. [CrossRef]

52. Payero, J.O.; Melvin, S.R.; Irmak, S.; Tarkalson, D. Yield response of corn to deficit irrigation in a semiarid climate. Agric. Water Manag. 2006, 84, 101-112. [CrossRef]

53. Jiao, L.; Lu, N.; Fu, B.; Wang, J.; Li, Z.; Fang, W.; Liu, J.; Wang, C.; Zhang, L. Evapotranspiration partitioning and its implications for plant water use strategy: Evidence from a black locust plantation in the semi-arid Loess Plateau, China. For. Ecol. Manag. 2018, 424, 428-438. [CrossRef]

54. Peake, A.S.; Carberry, P.S.; Raine, S.R.; Gett, V.; Smith, R.J. An alternative approach to whole-farm deficit irrigation analysis: Evaluating the risk-efficiency of wheat irrigation strategies in sub-tropical Australia. Agric. Water Manag. 2016, 169, 61-76. [CrossRef]

55. Lai, X.; Zhou, Z.; Zhu, Q.; Liao, K. Comparing the spatio-temporal variations of soil water content and soil free water content at the hillslope scale. Catena 2018, 160, 366-375. [CrossRef]

56. Guttieri, M.J.; Stark, J.C.; O’Brien, K.; Souza, E. Relative sensitivity of spring wheat grain yield and quality parameters to moisture deficit. Crop. Sci. 2001, 41,327-335. [CrossRef]

57. Zhang, X.; Chen, S.; Liu, M.; Pei, D.; Sun, H. Improved water use efficiency associated with cultivars and agronomic management in the North China Plain. Agron. J. 2005, 97, 783-790. [CrossRef]

(C) 2020 by the authors. Licensee MDPI, Basel, Switzerland. This article is an open access article distributed under the terms and conditions of the Creative Commons Attribution (CC BY) license (http://creativecommons.org/licenses/by/4.0/). 